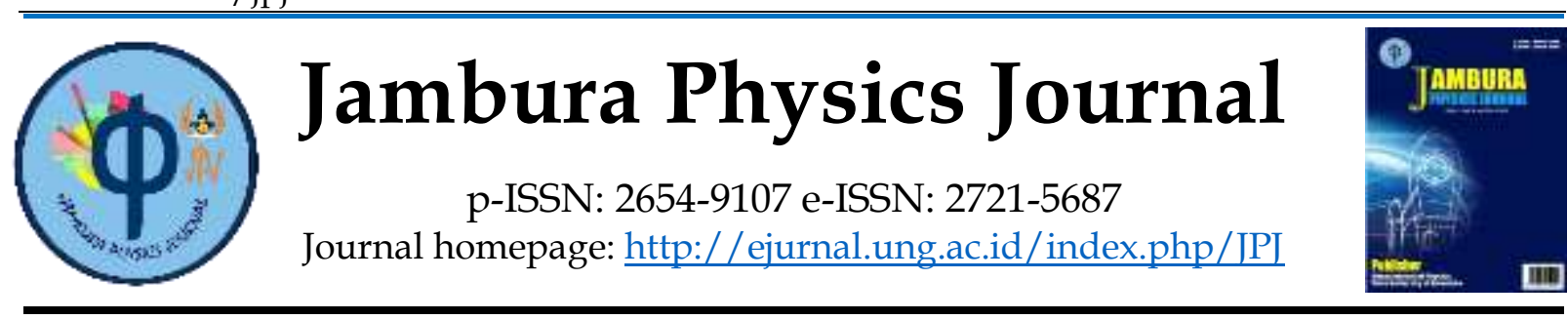

\title{
PENGARUH PENERAPAN MICROSOFT TEAMS TERHADAP KEMAMPUAN PEMECAHAN MASALAH SISWA DENGAN MENGGUNAKAN MODEL PEMBELAJARAN PROBLEM BASED LEARNING PADA MATERI GETARAN HARMONIS
}

\author{
Indrawan Hermanto Abdjul1, Mohamad Jahja ${ }^{2}$, Abd Wahidin Nuayi ${ }^{2 *}$, Asri Arbie ${ }^{2}$ \\ ${ }^{1}$ Program Studi Pendidikan Fisika, Jurusan Fisika Fakultas Matematika dan Ilmu Pengetahuan Alam \\ Universitas Negeri Gorontalo. Jl. Prof. Dr. Ing. B. J. Habibie Kecamatan Tilongkabila Kabupaten Bone \\ Bolango 96554, Indonesia \\ 2 Program Studi Fisika, Jurusan Fisika Fakultas Matematika dan Ilmu Pengetahuan Alam Universitas \\ Negeri Gorontalo. Jl. Prof. Dr. Ing. B. J. Habibie Kecamatan Tilongkabila Kabupaten Bone Bolango \\ 96554, Indonesia \\ "Email: wahidin.awn2023@ung.ac.id
}

Received: 15 July 2021. Accepted: 10 September. Published: 28 October 2021

\begin{tabular}{l} 
ARTICLE INFO \\
\hline Keywords: \\
Microsoft Teams; Problem \\
Solving Ability; Problem \\
Based Learning. \\
How to cite: \\
Abdjul, I.H., Jahja.M., \& \\
Nuayi, A.W., Arbie, A. \\
(2021). Pengaruh \\
Penerapan Microsoft \\
Teams Terhadap \\
Kemampuan Pemecahan \\
Masalah Siswa dengan \\
Menggunakan Model \\
Pembelajaran Program \\
Based Learning Pada \\
Materi getaran Harmonis. \\
Jambura Physics Journal, \\
3(2), 101-111 \\
DOI: \\
https://doi.org10.34312/ \\
jpj.v3i2.11229
\end{tabular}

This study aims to discover the influence of the Microsoft Teams implementation on students' problem-solving ability by using a problem-based learning model on the harmonic motion topic. This research is conducted in the odd semester of the 2020/2021 academic year. This study applies the experimental method. The study takes place at SMA Negeri 1 Popayato in grade XI with research subjects are XI IPA 1 graders amounted to 20 students' and XI IPA 3 graders amounted to 20 students'. The data collection uses were the assessment of students test results. However, the data analysis in this study uses the t-test. Based on the hypothesis test, it is obtained that $t_{\text {count }} 8.340>t_{\text {table }} 2.024$ with a significance level of a $=0.05$, then $H_{0}$ was rejected and $H_{1}$ was accepted, so it can be concluded that there is a significant effect on students' problem-solving abilities using Microsoft Teams on the Problem Based Learning model. 


\section{Pendahuluan}

Berdasarkan laporan PISA tahun 2018 performa Indonesia terlihat menurun jika dibandingkan dengan laporan PISA pada tahun 2015. Hal ini bisa dilihat dari tiga aspek yang dinilai dengan perolehan Indonesia pada indikator kemampuan membaca dengan skor rata-rata 397, kemampuan matematika 386 dan kemampuan kinerja sains 403 (OECD, 2018). Perolehan skor PISA 2018 untuk indikator kemampuan membaca dengan skor rata-rata 371, kemampuan matematika 379 dan kemampuan kinerja sains 389 dengan skor rata-rata OECD yakni 487. Dalam hal ini PISA 2018 menunjukkan bahwa Indonesia berada pada peringkat 9 dari bawah atau dalam kata lain berada pada peringkat 71 (Kemedikbud.go.id, 2019).

Data statistik hasil Ujian Nasional (UN) tahun 2019 untuk jenis satuan pendidikan SMA/MA Program Studi Ilmu Pengetahuan Alam dengan jumlah satuan pendidikan 14.564 (negeri dan swasta) dan jumlah peserta sebanyak 973.286 orang, menunjukkan bahwa perolehan nilai rata-rata dari keseluruhan mata ujian adalah 52,30 sedangkan pada mata ujian Fisika menunjukkan dengan nilai rata-rata yang dicapai adalah 45,79 sehingga pencapaian dalam mata ujian Fisika berkategori kurang berdasarkan nilai yang telah dicapai. Wilayah Provinsi Gorontalo dengan jumlah satuan pendidikan 87 (negeri dan swasta) dan jumlah peserta sebanyak 5.087 orang menunjukkan bahwa capaian nilai rata-rata keseluruhan mata ujian adalah 46,81 , sedangkan pada mata ujian fisika nilai rata-rata yang diperoleh adalah 40,77 sehingga pencapaian pada mata ujian fisika dalam kategori kurang atau rendah. Perolehan untuk Kabupaten Pohuwato sendiri dengan jumlah satuan pendidikan yaitu 10 (negeri \& swasta) dan jumlah peserta 616 orang menunjukkan dengan nilai rata-rata dari keseluruhan mata ujian adalah 42,68 , sedangkan untuk nilai rata-rata pada mata ujian Fisika adalah 36,43 dan juga dalam kategori kurang (Puspendik.kemedikbud.go.id, 2019).

Hasil wawancara dengan guru mata pelajaran FISIKA di SMA Negeri 1 Popayato diperoleh fakta bahwa hasil UN 2018/2019 pada mata pelajaran Fisika dengan ratarata nilai yang diperoleh adalah 34,70. Pembelajaran yang dilaksanakan terbukti kurang masksimal dengan salah satu masalah yang nyata adalah kurangnya kemampuan pemecahan masalah siswa dalam mata pelajaran Fisika. Kemampuan pemecahan masalah yang dimaksud adalah kemapuan pemecahan masalah siswa dalam menyelesaikan soal-soal yang telah diberikan. Sebagaimana yang diungkapkan oleh Alawiyah (2014:183) kemampuan pemecahan masalah adalah suatu aktivitas dalam menyelesaikan soal yang tidak rutin, memecahkan soal cerita, mengaplikasikan dalam kehidupan sehari-hari dan membuktikan. Siswa belum terlalu paham langkahlangkah apa yang harus diambil untuk lebih memudahkan dalam memecahkan masalah tersebut sehingga perlu adanya langkah-langkah yang terstruktur dan sistematis. Menurut Polya (dalam Susiyati, 2014:177), agar dapat memecahkan masalah ada empat proses yang dapat dilakukan yaitu memahami masalah, merencanakan penyelesaian, melaksanakan rencana dan memeriksa kembali.

Materi fisika rata-rata dianggap sulit oleh siswa. Hal ini terjadi karena kurangnya tingkat pemahaman siswa pada materi yang diajarkan sehingga tujuan dari pembelajaran minim tercapai. Di tambah lagi pada masa sekarang ini dengan hadirnya wabah Corona Virus Disease 19 (Covid-19) yang berdampak langsung pada sektor pendidikan yang mengakibatkan segala proses pembelajaran di alihkan ke 
Abdjul, I.H. et al./ Jambura Physics Journal (2021) Vol. 3(2): 101-111

dalam bentuk daring atau virtual. Permasalahan ini perlu adanya upaya mentaktisi keseimbangan dalam proses pembelajaran sehingga diperlukan media yang tepat untuk memaksimalkan pembelajaran daring tersebut dan juga model pembelajaran yang tepat untuk disesuaikan dengan pembelajaran tersebut, khususnya model pembelajaran yang mengacu pada proses pemecahan masalah.

Model pembelajaran Problem Based Learning adalah model pembelajaran yang diterapkan pada kurikuklum 2013 dengan memusatkan perhatian pada siswa. Adanya pembelajaran berbasis masalah membuat siswa merasa ingin tahu bagaimana hasilnya dan juga membuat siswa lebih cenderung aktif dalam pelaksanannya. Ali, dkk (2010:68) menerangkan bahwa In the problem based learning approach the student, turn from passive listeners of information receivers to active, free self-learner and problem solver. Artinya bahwa PBL merupakan sebuah approach pembelajaran yang berpusat pada siswa yang berubah dari pendengar pasif menjadi aktif, serta mengembangkan keterampilan pemecahan masalah. PBL di awali dengan orientasi siswa terhadap masalah, kemudian mengorganisasikan siswa terhadap masalah, setelah itu melakukan pembimbingan penyelidikan secara individu ataupun kelompok, mengembangkan dan menyajikan hasil karya dan terakhir menganalisis dan mengevaluasi proses pemecahan masalah dengan cara merekonstruksi pemikiran dan aktivitas yang telah dilakukan selama proses pembelajaran.

Media pembelajaran yang tepat sebagai pendukung dalam menggali kemampuan pemecahan masalah siswa adalah media yang dapat menunjang kelangsungan pada setiap fase dalam memecahkan masalah yang diberikan. Salah satu media yang dapat digunakan adalah Microsoft teams yang di prakarsai oleh Microsft dengan tujuan untuk menawarkan pengalaman belajar jarak jauh sebagai pribadi, menarik dan terhubung secara sosial seperti belajar dikelas. Microsoft teams hadir dengan tampilan dan fitur yang memadai sehingga memudahkan komunikasi dan interaksi antara sesama tanpa dibatasi ruang dan waktu. Microsoft Teams adalah platform komunikasi dan kolaborasi terpadu yang menggabungkan fungsi percakapan kerja, konferensi video, penyimpanan file dan integrasi aplikasi. Microsoft teams adalah layanan berbasis cloud yang menyediakan alat terbaik sehingga setiap orang atau pengguna dapat bekerja dengan cara yang modern. Menggabungkan aplikasi terbaik seperti Excel dan Outlook dengan layanan cloud canggih seperti One Drive dan Microsoft Teams di office 365 siapapun dapat membuat dan berbagi konten apapun diperangkat apapun, kapanpun dan dimanapun (Tim Dosen TSM, 2020:1).

\section{Metode}

Penelitian ini merupakan jenis penelitian dengan menggunakan metode ekperimen. Ali (2014:73) Eksperimen adalah penelitian yang dilakukan melalui eksperimen atau percobaan. Eksperimen mengacu pada upaya sadar untuk memodifikasi kondisi yang menentukan terjadinya suatu peristiwa, serta pengamatan dan interpretasi terkontrol dari perubahan yang terjadi pada peristiwa tersebut.

Penelitian ini dilaksanakan di SMA Negeri 1 Popayato, Kabupaten Pohuwato, Provinsi Gorontalo pada semester ganjil bulan september sampai dengan Januari tahun ajaran 2020/2021 dengan menyesuaikan jadwal mata pelajaran pada sekolah tersebut. 


\section{Rancangan penelitian}

Penelitian ini menggunakan desain True experimental. Sugiyono (2016:112) menyatakan bahwa dikatakan true experimental, karena desain ini dapat mengontrol semua variabel eksternal yang mempengaruhi proses eksperimen. Oleh karena itu, validitas internal (kualitas desain penelitian) bisa sangat tinggi. Fitur utama dari true experimental adalah bahwa sampel yang digunakan untuk kelas eksperimen dan kontrol dipilih secara acak dari populasi tertentu. Penelitian ini menggunakan bentuk Posttest-Only Control Design. Perlakuan yang diberikan pada kelas eksperimen berupa media Microsoft Teams dengan menggunkan model PBL, sedangkan perlakuan yang diberikan pada kelas kontrol berupa media Whatsapp dengan menggunakan model PBL. Populasi dalam penelitian ini adalah seluruh siswa kelas XI IPA SMA Negeri 1 Popayato tahun ajaran 2020/2021 yang terdiri dari 3 kelas. Pengambilan sampel dengan menggunkan tehnik Cluster Random Sampling sehingga diperoleh kelas XI IPA 3 sebagai kelas eskperimen dan kelas XI IPA 1 sebagai kelas kontrol.

\section{Teknik pengumpulan data}

Teknik pengumpulan data dalam penelitian ini adalah dengan menggunakan tes kemampuan akhir untuk memecahkan masalah siswa. Format tes berbentuk essay diberikan di akhir penelitian. Tes yang diberikan disesuaikan dengan indikator kemampuan pemecahan masalah polya yang terstruktur dan sistematis.

\section{Teknik analisis data}

Uji normalitas

Indra (2010:197) mengemukakan bahwa penggunaan statistik parametrik bekerja dengan asumsi bahwa data setiap variabel penelitian yang akan dianalisis membentuk distribusi normal. Uji normalitas adalah uji untuk mengetahui apakah data sampel terdistribusi normal. Statistik yang digunakan dalam uji normalitas adalah uji chikuadrat, sebagai berikut:

$$
\boldsymbol{X}^{\mathbf{2}}=\sum \frac{(\mathbf{f o}-\mathbf{f h})^{2}}{\mathbf{f h}}
$$

Keterangan :

$\mathrm{X}^{2}=$ Nilai normalitas hitung

Fo $=$ Frekuensi yang diperoleh dari data penelitian

$\mathrm{Fh}=$ Frekuensi yang diharapkan

Hipotesis statistik yang digunkan pada pengujian normalitas data yaitu :

Ho : Data berdistribusi normal

Ha : Data tidak berdistribusi normal

Penentuan $\mathrm{X}_{\text {tabel }}^{2}$ dengan $\mathrm{dk}=\mathrm{k}-1$ dan taraf signifikan 5\% dengan kaidah keputusan (Sugiyono, 2016:241):

Jika $\mathrm{X}_{\text {hitung }}^{2}>\mathrm{X}_{\text {tabel }}^{2}$ maka data berdistribusi tidak normal

Jika $\mathrm{X}_{\text {hitung }}^{2} \leq \mathrm{X}_{\text {tabel }}^{2}$ maka data berdistribusi normal

\section{Uji homogenitas}

Uji homogenitas yang akan digunakan pada penelitian ini adalah uji $\mathrm{F}$, sebagai berikut :

$$
\mathbf{F}_{\text {hitung }}=\frac{\text { variansi terbesar }}{\text { variansi terkecil }}
$$

Hipotesis statistik yang digunakan pada pengujian homogenitas data yaitu :

$$
\begin{aligned}
& H_{0}: \sigma_{1}^{2}=\sigma_{2}^{2} \\
& H_{1}: \sigma_{1}^{2} \neq \sigma_{2}^{2}
\end{aligned}
$$


$\mathbf{H}_{\mathbf{0}}=$ Varians data homogen

$\mathbf{H}_{\mathbf{1}}=$ Varians data tidak homogen

Setelah dilakukan pengujian, selanjutnya dibandingkan dengan harga $\mathrm{F}$ tabel dengan dk pembilang $=n_{1}-1$ dan dk penyebut $n_{2}-1$ dengan taraf signifikan $5 \%$. Kaidah keputusan (Sugiyono, 2016:275):

Jika $\mathbf{F}_{\text {hitung }}>\mathbf{F}_{\text {tabel }}$ maka data tidak homogen

Jika $\mathbf{F}_{\text {hitung }} \leq \mathbf{F}_{\text {tabel }}$ maka data homogen

Uji hipotesis

Pengujian hipotesis dilakukan untuk mengetahui apakah terdapat pengaruh signifikan penggunaan Microsoft teams terhadap kemampuan pemecahan masalah siswa dengan menggunakan model PBL ditinjau dari posttest siswa pada kelas ekperimen dan kelas kontrol yang diberikan perlakuan berbeda. Pengujian hipotesis dalam penelitian ini menggunakan uji statistika parametric dengan statistika uji $t$-test untuk mengetahui perbedaan signifikan antara kelas eksperimen dan kelas kontrol berdasarkan data yang diperoleh dalam penelitian, dengan rumus The pooled variance model $t$-test sebagai berikut:

$t=\frac{\overline{\mathrm{X}}_{1}-\overline{\mathrm{X}}_{2}}{\sqrt{\frac{\left(\mathrm{n}_{1}-1\right) \mathrm{S}_{1}^{2}+\left(\mathrm{n}_{2}-1\right) \mathrm{S}_{2}^{2}}{\mathrm{n}_{1}+\mathrm{n}_{2}-2}\left(\frac{1}{\mathrm{n}_{1}}+\frac{1}{\mathrm{n}_{2}}\right)}}$

Keterangan:

$\overline{\mathrm{X}}_{1}=$ Rata-rata kelas eksperimen

$\overline{\mathrm{X}}_{2}=$ Rata-rata kelas kontrol

$\mathrm{n}_{1}=$ Banyaknya sampel kelas eksperimen

$\mathrm{n}_{2}=$ Banyaknya sampel kelas kontrol

$\mathrm{S}_{1}^{2}=$ Harga varian kelas eksperimen

$\mathrm{S}_{2}^{2}=$ Harga varian kelas kontrol

(Sudjana, 2005:239)

Pengujian hipotesis statistik dalam penelitian ini adalah sebagai berikut:

$\mathbf{H 0}: \boldsymbol{\mu}_{\mathbf{1}}=\boldsymbol{\mu}_{\mathbf{2}} \quad$ (Tidak terdapat perbedaan signifikan kemampuan pemecahan masalah siswa yang dibelajarkan dengan menggunakan Microsoft teams dengan kemampuan pemecahan masalah siswa yang dibelajarkan dengan menggunakan Whatsapp)

$\mathbf{H 1}: \boldsymbol{\mu}_{\mathbf{1}} \neq \boldsymbol{\mu}_{\mathbf{2}} \quad$ (Terdapat perbedaan signifikan kemampuan pemecahan masalah siswa yang dibelajarkan dengan menggunakan Microsoft teams dengan kemampuan pemecahan masalah siswa yang dibelajarkan dengan menggunakan Whatsapp)

Taraf signifikansi $\alpha=0,05$, maka kriteria pengambilan keputusan:

Jika $t_{\text {hitung }}>\mathrm{t}_{\text {tabel }}$ maka $\mathrm{H}_{0}$ ditolak

Jika $t_{\text {hitung }}<t_{\text {tabel }}$ maka $\mathrm{H}_{0}$ diterima

\section{Hasil dan Pembahasasn}

\section{Deskripsi data hasil penelitian}

Data hasil tes pemecahan masalah siswa diperoleh dari pemberian sebanyak 6

butir tes pemecahan masalah pada kelas eksperimen dengan jumlah siswa 20 orang dan kelas kontrol dengan jumlah siswa 20 orang. Data yang diperoleh merupakan data posttest setelah diberikannya perlakuan pada kelas eksperimen yang 
Abdjul, I.H. et al./ Jambura Physics Journal (2021) Vol. 3(2): 101-111

menggunakan Microsoft Teams dengan model PBL dan kelas kontrol menggunakan Whatsapp dengan model PBL. Secara umum gambaran data dari kemampuan pemecahan masalah siswa dapat dilihat pada tabel 1 .

Tabel 1. Data kemampuan pemecahan masalah siswa

\begin{tabular}{llllll}
\hline Kelas & N & Skor Ideal & Skor max & Skor min & Rata-rata \\
\hline Eksperimen & 20 & 100 & 97 & 44 & 80.44 \\
Kontrol & 20 & 100 & 93 & 40 & 70.03 \\
\hline
\end{tabular}

Presentase rata-rata kemampuan pemecahan masalah siswa pada kelas eksperimen dan kelas kontrol jelas berbeda. Kemampuan pemecahan masalah siswa pada kelas eksperimen menunjukkan rata-rata nilai sebesar 80.44 sedangkan pada kelas kontrol menunjukkan rata-rata nilai sebesar 70.03. Hal ini menunjukkan terdapat perbedaan kemampuan pada kelas eksperimen dan kontrol dengan selisih yang ada. Hal ini pun menunjukkan bahwa adanya pengaruh variabel bebas melalui konten pembelajaran yang ditonjolkan dengan menggarap kemampuan pemecahan masalah siswa pada materi getaran harmonis. Adapun kemampuan pemecahan masalah untuk setiap indikator ditampilkan pada tabel 2.

Tabel 2. Kemampuan pemecahan masalah siswa tiap indikator

\begin{tabular}{|c|c|c|c|}
\hline \multirow{2}{*}{ Indikator kemampuan pemecahan masalah } & \multicolumn{2}{|c|}{ Rata- rata skor } & \multirow{2}{*}{ Skor ideal } \\
\hline & Eksperimen & Kontrol & \\
\hline Memahami Masalah & 19.46 & 16.65 & 20 \\
\hline Merencanakan Penyelesaian & 15.57 & 14.78 & 16 \\
\hline Melaksanakan Rencana atau Solusi & 42.13 & 36.05 & 58 \\
\hline Memeriksa Kembali & 3.28 & 2.55 & 6 \\
\hline
\end{tabular}

Presentase setiap indikator pemecahan masalah siswa untuk kelas eksperimen (menggunakan Ms.Teams) dan kelas kontrol (menggunakan Whatsapp) sebagaimana ditampilkan pada gambar 1. Dari gambar 1 tampak bahwa kemampuan pemecahan masalah siswa antara kelas eksperimen dan kelas kontrol terlihat mengalami perbedaan pada setiap indikator pemecahan masalah. Indikator memahami masalah pada kelas eksperimen dengan perolehan rata-rata 19,46 sedangkan pada kelas kontrol dengan rata-rata 16,65 . Indikator melaksanakan rencana atau solusi pada kelas eksperimen dengan rata-rata 42,13 sedangkan pada kelas kontrol dengan rata-rata 36,05. Indikator merencanakan penyelesaian dan memeriksa kembali terlihat terdapat perbedaan yang tidak begitu jauh. Hal ini disebabkan karena pada Microsoft teams dan whatsapp memiliki fitur yang sama-sama bekerja untuk saling berbagi informasi, gambar, video, bahkan dokumen, sehingganya pada tahap merencanakan penyelesaian siswa bisa saling lebih aktif berkomunikasi dan kolaboratif dan matang dalam perencanaannya, sedangkan pada indikator memeriksa kembali disebabkan karena kurangnya partisipasi dan kesadaran siswa dalam memeriksa kembali masalah yang telah dipecahkan sehingganya indikator terakhir ini minim tercapai pada kedua kelas tersebut. Indikator memeriksa kembali dinilai dari kemampuan siswa dalam menganalisis dan mengevaluasi apakah prosedur yang diterapkan dan hasil yang diperoleh sudah benar atau tidak dan sebagai akhir dalam proses ini adalah siswa dituntut untuk memberikan kesimpulan dari jawaban yang diperoleh. 


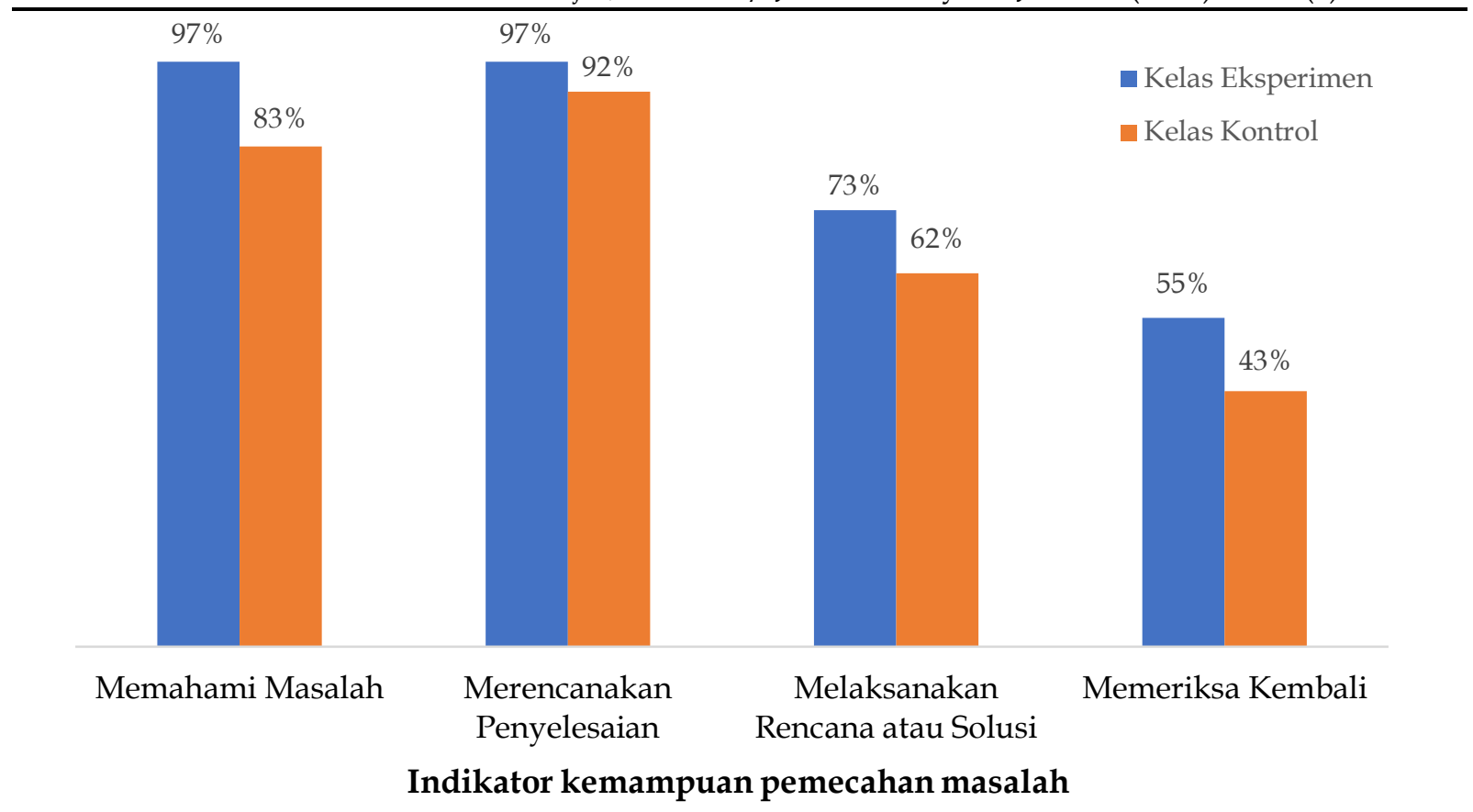

Gambar 1. Persentase skor rata-rata Kemampuan Pemecahan Masalah Siswa Tiap Indikator

\section{Uji Normalitas Data}

Uji normalitas digunakan untuk mengetahui apakah data sampel yang didapatkan berdistrubusi normal atau tidak dengan statistika yang digunakan adalah uji chi kuadrat. Berikut merupakan tabel 3 hasil uji normalitas data.

Tabel 3. Hasil pengujian normalitas data

\begin{tabular}{llll}
\hline Kelas & $\mathbf{X}^{\mathbf{2}}$ Hitung & $\mathbf{X}^{\mathbf{2}}$ Tabel & Status \\
\hline Eksperimen & 6.691 & 11.070 & Berdistribusi Normal \\
Kontrol & 4.727 & 11.070 & Berdistribusi Normal \\
\hline
\end{tabular}

Berdasarkan tabel 3 pada kelas eksperimen dan kelas kontrol diperoleh $\mathbf{X}^{2}$ Hitung $<\mathbf{X}^{2}$ Tabel dengan taraf nyata $\alpha=0.05$ maka $\mathrm{H}_{0}$ diterima dalam artian data pada kelas eksperimen dan kelas kontrol terdistribusi normal.

\section{Uji Homogenitas}

Uji homogenitas digunakan untuk memeriksa apakah varians datanya homogen. Uji homogenitas yang digunakan dalam penelitian ini adalah uji $F$ dengan membandingkan varians kedua sampel dan hasil pengujian homogenitas dapat dilihat pada tabel 4 berikut.

Tabel 4. Hasil pengujian homogenitas data

\begin{tabular}{llll}
\hline Kelas & $\mathbf{F}_{\text {Hitung }}$ & $\mathbf{F}_{\text {Tabel }}$ & Status \\
\hline $\begin{array}{l}\text { Eksperimen } \\
\text { Kontrol }\end{array}$ & 1.024 & 2.168 & Homogen \\
\hline
\end{tabular}

Berdasarkan tabel 4 setelah dibandingkan harga varians kelas eksperimen dan kelas kontrol maka didapatkan $\mathrm{F}_{\text {Hitung }}<\mathrm{F}_{\text {Tabel }}$ dengan taraf nyata $\alpha=0.05$ maka $\mathrm{H}_{0}$ diterima dalam artian data bersifat homogen. 


\section{Uji Hipotesis}

Uji hipotesis merupakan uji yang digunakan untuk melihat apakah terdapat pengaruh signifikan dari perlakuan yang diberikan terhadap kemampuan pemecahan masalah siswa dengan uji yang digunakan adalah uji t dua sampel independen. Hasil uji statistik dapat dilihat pada tabel 5 berikut.

Tabel 5. Hasil pengujian hipotesis

\begin{tabular}{llll}
\hline Kelas & $\mathbf{t}_{\text {Hitung }}$ & $\mathbf{t}_{\text {Tabel }}$ & Status \\
\hline $\begin{array}{l}\text { Eksperimen } \\
\text { Kontrol }\end{array}$ & 8.340 & 2.024 & $\mathrm{H}_{0}$ di tolak \\
\hline
\end{tabular}

Berdasarkan tabel 5 diperoleh $t_{\text {Hitung }}>t_{\text {tabel }}$ dengan taraf nyata $\alpha=0.05$. Maka $\mathrm{H}_{0}$ ditolak dan $\mathrm{H}_{1}$ diterima. Artinya terdapat perbedaan signifikan kemampuan pemecahan masalah siswa yang dibelajarkan dengan menggunakan Microsoft teams dengan kemampuan pemecahan masalah siswa yang dibelajarkan dengan menggunakan Whatsapp.

\section{Pembahasan}

Dalam penerapan pendidikan yang baik dan mampu bersaing dalam menciptkan mutu pendidikan yang merata dan maksimal membutuhkan kualitas pendidikan yang benar-benar mampu mengakomodir setiap kalangan pelajar meskipun dalam keadaan yang sulit. Utamanya dalam wabah internasional yang terus berlanjut yakni Coronavirus Disease 2019. Pendidikan yang diterapkan di sekolah melalui proses pembelajaran antara guru dan siswa yang dilaksanakan secara online memiki banyak tantangan dalam pelaksanaannya. Penggunaan media yang tepat dapat membawa hasil yang tepat pada kegiatan pembelajaran yang dilaksanakan. Berangkat dari hal tersebut maka penelitian ini dilakukan dengan alasan yang benarbenar konkret dan mendasar.

Penelitian ini dilaksanakan di SMA Negeri 1 Popayato pada semester ganjil tahun ajaran 2020/2021 yang bertujuan untuk melihat pengaruh penerapan Microsoft teams terhadap kemampuan pemecahan masalah siswa dengan menggunakan model PBL pada materi getaran harmonis. Perlakuan yang diberikan dengan harapan untuk membuat pembelajaran tidak hanya menjadi satu arah yang berpusat pada guru saja, tetapi keaktifan seorang siswa sangat diperlukan dalam proses pembelajaran dan juga melatih kemampuan siswa dalam memecahkan masalah matematis yang ada demi terwujudnya hasil belajar yang maksimal sebagaimana yang telah diungkapkan oleh (Alcantara, 2017:21) bahwa kemampuan pemecahan masalah yaitu kemampuan menemukan jalan dan menemukan solusi untuk masalah yang tidak diketahui. Proses pembelajaran menggunakan pemecahan masalah memungkinkan siswa untuk merekonstruksi atau membangun kembali pengetahuannya sendiri berdasarkan pengetahuan yang dimilikinya, sehingga proses pembelajaran dapat berjalan aktif dan dinamis.

Kegiatan pembelajaran pada kelas eksperimen dan kontrol selalu diawali dengan pemberian apersepsi dan motivasi kepada siswa guna untuk memberikan stimulus kepada siswa terkait dengan penanaman pengetahuan lama ke pengetahuan baru ataupun mendesain pengetahuan yang baru saja didapatkan. Selanjutnya pada kegiatan inti siswa lebih dilatih untuk berperan secara aktif melalui kelompok yang 
Abdjul, I.H. et al./ Jambura Physics Journal (2021) Vol. 3(2): 101-111

sudah dibagi dengan mengerjakan LKPD melalui langkah-langkah yang sudah dibimbing oleh peneliti. LKPD yang diberikan memuat masalah yang harus dipecahkan oleh siswa sehingga dapat menimbulkan respon yang kritis dari siswa dalam mengambil setiap langkah dalam proses pemecahan masalah. Kemampuan pemecahan masalah sangat penting bagi siswa dalam menghadapi tantangan pada proses pembelajaran. Sebagaimana yang diungkapkan oleh Jaenab (2014:254) bahwa kemampuan pemecahan masalah membantu siswa lebih berpikir analitis ketika membuat keputusan dalam kehidupan sehari-hari, dan membantu meningkatkan keterampilan berpikir kritis ketika berhadapan dengan situasi baru.

Berdasarkan pengolahan data hasil penelitian diperoleh hasil kemampuan pemecahan masalah siswa pada mata pelajaran fisika materi getaran harmonis pada kelas eksperimen jauh lebih unggul dibandingkan dengan kelas kontrol setelah diberikannya treatment yang sesuai pada rancangan penelitian. Hal ini dibuktikan dengan perolehan nilai rata-rata kemampuan pemecahan masalah pada kedua kelas tersebut. Lebih jauh lagi jika ditinjau dari setiap indikator pada pemecahan masalah yang sudah di susun sedemikian rupa oleh peneliti terdapat perbedaan kemampuan pada setiap indikator pemecahan masalah siswa antara kelas eksperimen dan kelas kontrol diantaranya indikator memahami masalah rata-rata skor kelas eksperimen 19.46 sedangkan kelas kontrol 16.65, merencanakan penyelesaian atau solusi rata-rata skor kelas eksperimen 15.57 sedangkan kelas kontrol 14.78, melaksanakan rencana solusi rata-rata skor kelas eksperimen 42.13 sedangkan kelas kontrol 36.13 dan memeriksa kembali rata-rata skor kelas eksperimen 3.28 sedangkan kelas kontrol 2.55. Perbedaan pada kelas tersebut disebabkan pada penggunaan media pembelajaran yang digunakan. Microsoft teams unggul karena memiliki fitur meeting dan sharing yang diaplikasikan pada proses pembelajaran, sedangkan whatsapp mengandalkan fitur chat dan video call group serta kemudahan dalam mengoperasikannya. Berdasarkan hal tersebut sehingganya dapat disimpulkan bahwa terdapat perbedaan kemampuan pemecahan masalah siswa pada kelas eksperimen dan kelas kontrol. Sebagaimana penelitian yang dilakukan oleh (Aulia, 2020) kesimpulannya bahwa menurut kategori keberhasilan yang ditetapkan, kemampuan pemecahan masalah siswa dapat dikatakan baik yaitu sebanyak 23 siswa (68\%) dalam kategori pemecahan masalah baik atau sangat baik.

Berdasarkan tabel hasil uji t dua sampel independen diperoleh nilai $t_{\text {hitung }}$ lebih

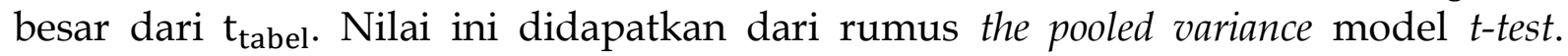
Berdasarkan pengujian hipotesis tersebut dapat disimpulkan bahwa terdapat pengaruh signifikan penerapan Microsoft teams terhadap kemampuan pemecahan masalah siswa dengan menggunakan model PBL. Hasil yang dberikan melalui penerapan Microsoft Teams dengan menggunkan model PBL membawa pengaruh yang positif bagi siswa meskipun pembelajaran dilaksanakan ditengah pandemi Covid-19. Fitur yang diberikan Microsoft Teams menunjang siswa dalam melaksanakan setiap indikator kemampuan pemecahan masalah. Kestersediaan fitur seperti Channel, Chat group, assignments, meeting, file dan sharing dapat menunjang dalam proses pembelajaran. Hal ini sejalan dengan penelitian yang dilakukan oleh Diana (2020) yang menunjukkan bahwa interaksi antara pendidik dan siswa lebih mudah dan lebih aktif. Fasilitas yang disediakan oleh Microsoft teams membuat pendidik dapat lebih mudah mengkomunikasikan materi kepada siswa. Demikian juga siswa dapat 
Abdjul, I.H. et al./ Jambura Physics Journal (2021) Vol. 3(2): 101-111

berinteraksi dengan pendidik dan teman secara fleksibel karena tidak dibatasi oleh ruang dan waktu.

Penelitian ini menunjukkan bahwa penerapan Microsoft teams dengan menggunakan model PBL berpengaruh signifikan terhadap kemampuan pemecahan maslah siswa jika dibandingkan dengan menggunakan whatsapp. Hal ini dibuktikan oleh rata-rata hasil perolehan nilai dengan menggunakan Microsoft Teams berada pada 80.44 dengan nilai tertinggi adalah 97 dan nilai terendah adalah 44, sedangkan yang dengan menggunakan whatsapp di peroleh nilai rata-rata 70.03 dengan nilai tertinggi adalah 93 dan nilai terendah adalah 40

\section{Kesimpulan}

Terdapat pengaruh signifikan penerapan Microsoft Teams terhadap kemampuan pemecahan masalah siswa dengan menggunakan model PBL yang dimana penerapan Microsoft Teams sebagai media dalam pembelajaran yang kemudian dengan menggunakan model pembelajaran PBL dalam proses pembelajaran merupakan sesuatu yang cocok untuk diintegerasikan dalam menggarap kemampuan pemecahan masalah siswa.Hal ini ditunjukkan melalui kriteria pengujian hipotesis yang dimana $t_{\text {hitung }}>t_{\text {tabel }}$. Adapun rata-rata yang diperoleh pada kelas eksperimen yaitu 80.44 dan pada kelas kontrol yaitu 70.11.

\section{Referrensi}

Alawiyah, T. (2014). Pembelajaran untuk Meningkatkan Kemampuan Komunikasi dan Pemecahan Masalah Matematik. Prosiding Seminar Nasional Pendidikan Matematika, Vol.1, ISSN 2355-0473, 180-187

Alcantara, E. C., Bacsa, J. M. P., \& City, B. (2017). Critical Thinking and Problem Solving Skills in Mathematics of Grade-7 Public Secondary Students. Asia Pacific Journal of Multidisciplinary Research, 5(4), 21-27.

Ali, Mohamad, M. A. (2014). Metodologi dan Aplikasi Riset Pendidikan. Jakarta: PT Bumi Aksara.

Ali, R., \& Akhter, A Science, A. K. (2010). Effect of using problem solving method in teaching mathematics on the achievement of mathematics students. Citeseer, 6, 2.

Aulia, D.S. (2020). Upaya Meningkatkan Kemampuan Menyelesaikan Masalah Matematika Melalui Guided Discovery Learning Menggunakan Microsoft Teams Berbantuan Excel. Postulat: Jurnal Inovasi Pendidikan Matematika 1(2) 98-108.

Diana, R \& Nana. (2020). Implementasi Model Poe2we Dalam LKS Materi Elastisitas Bahan Dengan Menggunakan Microsoft Teams Untuk Meningkatkan Kualitas Pembelajaran Fisika. https://doi.org/10.31219/osf.io/9tbxu.

Jaenab, S. (2014). Pembelajaran Matematika untuk Meningkatkan Kemampuan Pemecahan Masalah Matematis Siswa Sekolah Menengah Kejuruan. Prosiding Seminar Nasional Matematika, Vol.1, ISSN 2355-0473, 254-258. 
Abdjul, I.H. et al./ Jambura Physics Journal (2021) Vol. 3(2): 101-111

Jaya,I. (2010). Statistik Penelitian Untuk Pendidikan. Bandung: Citapustaka Media Perintis

Kemedikbud.go.id. (2019). Hasil PISA Indonesia 2018: Akses Makin Meluas, Saatnya Tingkatkan Kualitas. https://www.kemedikbud.go.id (Diakses pada 3 Maret 2020)

OECD. (2018). What Is PISA? http://www.oecd.org/pisa/ (Diakses pada 3 Maret 2020).

Puspendik.kemedikbud.go.id. (2019). LAPORAN HASIL UJIAN NASIONAL. Https:/ Puspendik.Kemedikbud.Go.Id/Hasil-Un/.(Diakses pada 3 Maret 2020).

Sudjana.(2005). Metoda Stastika. Bandung: Tarsito.

Sugiyono. (2016). Metode penelitian pendidikan: (pendekatan kuantitatif, kualitatif dan R \& D). Bandung: Alfabeta.

Susiyati. (2014). Kemampuan Berpikir Kritis dan Kreatif Matematik dalam Pemecahan Masalah. Prosiding Seminar Nasional Pendidikan Matematika, Vol.1, ISSN 23550473, 171-179.

Tim Dosen TSM. (2020). Panduan Penggunaan Microsoft 365. Jakarta: Trisakti School of Management. 